\section{II-3. 各国の救急車のデザインと装備}

消防大 岡村正明

\section{II-4. 救急医療のM E 機器}

日本光電工業 篠 原 輝 雄

救急車は世界各国共1960年代までは，いずれ も救急現場から医療機関一の輸送が主たる任務 であり，したがって救急車は迅速性に収容した 患者を仰臥位でできるだけ安静であるための安 定性，操縦性，加速性ということに主眼が抢か れ，それにプラスして輸送間の若干の手当，主 として, 外出血に対する止血, 骨折の固定, 呼 吸管理のための酸素吸入に必要な器材が常備さ れているものがほとんどあった。

しかし1960年の後半からは，事故㘯るいは急 性心不全等の生命に著しく危機を招来するよう な患者の場合は，現場及び医療機関に輸送間の 緊急医療特に救命医療が極めて重要であること が認識され，救急車もこれまでの輸送を主力と するものから，現場あるい悇内で緊急救命医 療の可能な救急車の設計装備に重点が急がれ， 例えば西ドイッでは，これまでの輸送を主体と するKranken Wagen (KW) 以外に現場及び 車内で必要な医療が行い得てしかも医師の同乗 寸る Not Arzt Wagen (NAW) が救急車と して重要な位置を占めるに至った。またアメリ 力合衆国に捛いては1966年政府と関係機関によ り Mobile Intensive Care Unitとしての能力 をもちうる救急車としての設計基準が示され， 救急車はこれまでの輸送主体のものから大き く，その任務も改如られる至った。さらにこ の傾向はヨーロッパ各国，オーストラリア等で も展開し，現在世界の多くの国々では具体的に はそれぞれの国情を反映しているものの基本的 には現場及び輸送間車内での救命緊急医療の可 能なものへと移行している.

ここでは，その $2 \sim 3$ の実情について紹介し てみたいと思っている。
まず，救急医療に用いられる $\mathrm{ME}$ 機器に要求 される基本的な事項についてのべる．救急医療 に用いられるME機器を分類すると, 救急現場 に抢ける診察・診断及び蘇生を目的とした機器 群と，主として第 2 次救急医療施設以降で用い られる生命維持・管理を目的とした機器群とに 大別される. 前者は心電計, 除細動器, 人工呼 吸器等であり, 後者は心臟ペースメーカ, I C U用患者監視装置や検体検查機器等である。い ずれの群にも要求されることは，緊急時に使用 される機器であるから，まず小型軽量でしかも 操作性が優れていること，また緊急時に故障の ないよう特に高い信頼性を持っこと, 及び万一 誤操作があっても患者はもちろんのこと，医師 や介助者に危険のないよう安全性の高いこと等 である，次㥁者の症状も多岐にわたっている ので，できるだけ複合された機能をもち，しか も機動性の高い装置であることや，場所をとら ず治療・看護の邪魔にならないことが大切であ る.

次に, ME機器の組合せやシステムについて 用のドクターズカーやモービル C C U 等であ り，後者には以下のようなものがある。

近年, 実用の段階に入った心電図の電話伝送 システムは，救急現場から，また患者搬送中も 受入れ側の医師に情報を迅速に伝達でき，また プレホスピタルケアや，アフターケアに大いに 役立つシステムである。

生命維持・管理の代表的システムには，急性 の重症患者を收容して集中的に全身管理する I C Uシステムがあり，近年は専門分科され心不 全の C C U, 脳卒中の S C U, 重症新生児の $\mathrm{N}$ $\mathrm{CU}$ 等の特殊診療ユニットのシステムも機能し 始めている.

今後，救急医療の体制が確立され，それに則 したME機器・システムが開発されてそれ等に よる救命率の向上が期待される. のべる．前者は上位救急医療施設への患者搬送 